\title{
Developing Urban Community Garden Projects ${ }^{1}$
}

\author{
Austen Moore, Amy Harder, and Norma Samuel ${ }^{2}$
}

\section{Introduction}

This publication provides a guide to individuals or groups interested in starting urban community gardens and includes information about how to identify garden sites, build partnerships, engage community members, and develop a project overview.

\section{Urban Community Gardens}

Community gardens are pieces of land where groups of people grow and maintain vegetable and flower plants (American Community Gardening Association [ACGA], n.d.). They exist in all types of areas, including neighborhoods, at schools, or on other public or private lands. Community gardens grow food for local consumption or sale and can also be used for teaching gardening and other skills (Gardening Matters, 2009). The benefits of community gardens include the following:

- Growing fresh and healthy foods

- Reducing food costs

- Learning new skills and abilities

- Encouraging empowerment and self-reliance

- Building a sense of community

- Encouraging social interactions across cultures and generations
- Developing and beautifying neighborhoods

- Creating opportunities for recreation, exercise, and education (ACGA, n.d.)

\section{Project Development}

Several tasks are necessary when developing an urban community garden project. The following information will help create a solid foundation for your project.

\section{Brainstorm general locations}

Step 1: First, brainstorm some general locations for your urban community garden project. These could include a region, county, city, or other large area. You do not need to narrow this area down yet. However, many urban community garden projects are started with a neighborhood or location already in mind. In this case, you can move on to step five.

\section{Conduct a community needs assessment}

Step 2: Next, think about needs and/or benefits of community gardens for different areas. Not all communities need or want a garden project. It is important to know that a community is a good fit before moving forward with your project. For each of the areas you brainstormed in the first step, write down what you think their needs are or how a community garden would benefit them. Thinking this through will help you better select a community for the garden project.

1. This document is WC139, one of a series of the Agricultural Education and Communication Department, Florida Cooperative Extension Service, Institute of Food and Agricultural Sciences, University of Florida. Original publication date March 2013. Visit the EDIS website at http://edis.ifas.ufl. edu.

2. Austen Moore, doctoral student, and Amy Harder, associate professor, Agricultural Education and Communication Department; Norma Samuel, Urban Horticulture Agent, Marion County Cooperative Extension; University of Florida Institute of Food and Agricultural Sciences, Gainesville, FL 32611. 
Step 3: At this point, you should have narrowed down the potential areas for your urban community garden. Next, conduct more in-depth community needs assessments. One option is to walk through each potential project area observing conditions (land use, social interactions, etc.), seeking problems, and considering possible opportunities (Food and Agriculture Organization [FAO], n.d.). This will give you a quick overview of the area.

- Consider safety before you walk. Avoid walking at night and walk together with a partner. If you can walk with a member of the community, you will be safer and learn more about the area at the same time.

- Introduce yourself and talk with the people you encounter as you walk. Asking about prior gardening experience is a good way to break the ice. Also ask whether the community is interested in a garden project, or if there are any current or past garden projects. If there is interest, perhaps community members can suggest possible locations. If people are not interested, then consider a different community or area.

- Take good notes during your walk. Record descriptions of the area, the people, or anything else that might be important. Write down any observations about gardening, such as whether container gardens, potted plants, or landscaping are present.

- Draw a quick map of the area after your walk (FAO, n.d.). Include important buildings and locations. Also consider possible garden sites.

\section{Select a community garden site}

Step 4: Next, use the information from your needs assessment walks and conversations with community members to identify the site for your garden project. Before making any final decisions, consider the following:

- Think about the site's characteristics for growing plants. Sites should have good soil quality or room for benches/ raised beds, an available water source, enough sunlight, and be free from pollution (Hansen, Sewards, Almeida, \& Dunn, 2012).

- Consider convenience for possible participants. People can spend more time in the garden if locations are central and within easy walking distance. This results in healthier plants and greater local ownership of the community garden (ACGA, n.d.).
- Locate the community garden in a place that is public, well-lit, and possibly fenced to help reduce the loss or destruction of plants from theft and vandalism (Gardening Matters, 2009).

- Find out who owns the land. Your city or county's tax assessor's office has this information (Gardening Matters, 2009).

Once you have considered these issues, you can make an informed decision about which site is best for your urban community garden project.

\section{Recruit partners outside your community}

Step 5: First, identify any current urban community gardens in your city. A simple Internet search will get you started. Contact the leaders of these projects to learn about their operations and experiences. They may provide information to help you develop your own garden project. Existing projects may also be willing to partner or include your project under their umbrella. This could grant access to their network of partners, donors, and technical information. Being linked to an existing project can also help build your public credibility.

Step 6: Think about any people or organizations whose support you need to have for a successful project. You may need approval for legal reasons (Public Health Law Center [PHLC], 2012). For example, you may need permission from your city to build a community garden. This is especially true if you plan to use city land. Other organizations may be needed to work with certain groups of participants (students, seniors, low-income citizens, etc.). This depends on the communities and types of people you hope to include in the project.

Step 7: Other partners should be identified based on your project's needs.

- If your project does not already have land, you need a partner that can contribute a garden site to the project. Start from the sites you originally identified and see if any of the landowners could be potential partners.

- Partnering with local businesses can help if gardening supplies (plants, seeds, tools, etc.) are needed (ACGA, n.d.).

- If your community does not have much gardening experience, you should find partners who can help provide training and technical information. Your local Extension office and Master Gardener volunteers can be 
good partners for your project (Worden, Hunsberger, \& McLaughlin, 2002).

- Other partners could be a source of funds. Contact those organizations that might seem unlikely to contribute. They may become involved for the marketing or public relations benefits.

\section{Recruit partners inside your community}

Step 8: It is very important to find community organizations to partner with your project (ACGA, n.d.). Including neighborhood groups, churches, or other local organizations gives your project legitimacy in the community, helps build trust, and increases participation. However, sometimes there are not established community organizations. In these cases, you may need to focus on individual community leaders instead (see step nine).

Step 9: Including influential community leaders in your project is very important. Their involvement can help increase local buy-in and participation (Swisher, Rezola, \& Sterns, 2003). There are many ways to identify leaders in your community. Ask your partners and other community organizations for help. Community members may also help you find the community leaders whose actions and beliefs influence others.

\section{Create an advisory council}

Step 10: At this point, you should have identified important partners from inside and outside of the community. Key people from your partner groups should be asked to form an advisory council for the project. This council allows different groups to communicate and work together to develop a successful project (McKinney, 2007).

\section{Develop a project overview}

Step 11: At this stage, you should identify the general objectives and outcomes of your project. There are many ways to consider and document these, and the logic model is a very useful option. Building a logic model allows you to think through some of the inputs, activities, and contextual factors that may impact the project. See Extension documents from the University of Florida and the University of Wisconsin for more information about logic models (Israel, 2010; University of Wisconsin Extension, 2012).

Step 12: Next, draft a tentative schedule for your urban community garden.

- Think about the timeline of your project. Design your plan around local growing cycles, even if the project will be ongoing (Gardening Matters, 2009). Think about when to plant, what to grow during certain times of year, and what garden maintenance is required. All of this information is available through your county's Extension office.

- Start your schedule from the planting dates in your area and then plan backwards. Be sure to include time for any activities or meetings you need before starting to garden. You need time before your local plant date to obtain and prepare a site, form partnerships, and develop interest in the community. Think about how long each of these activities will take and plot them on a yearly calendar.

Step 13: Create a plan of activities for the growing period of your urban community garden.

- First, decide how much training you need based on your needs assessments and conversations with community members. If most people in your area already have gardening knowledge and experience, you may not need many sessions. However, communities with less gardening experience may require more guidance and training to succeed in the project.

- Also consider the types of activities or training needed during the gardening cycle. This depends on the needs of your community. Some options include the following:

1. Building Raised Beds

2. Preparing Garden Soil

3. Planting Gardens

4. Composting

5. Watering and Irrigation

6. Weed and Pest Control

7. Harvesting Gardens (ACGA, n.d.)

Sessions on cooking and preserving garden vegetables may also be useful for audiences without much experience.

- Create a calendar of activities when you decide which sessions to include (Gardening Matters, 2009). Plan these activities around your local growing cycle, working backwards from harvest. Choose a frequency of sessions (weekly, biweekly, monthly, etc.) that covers all topics and keeps participants engaged. Add some flexibility or open spaces into the calendar in case other training sessions are needed. 


\section{Introduce the project}

Step 14: Next, find ways to introduce the project to your community. Informational materials are a good option. Be sure to carefully consider your audience when creating these pieces.

- Any materials you create should be concise, use simple terms, and contain effective pictures (Gardening Matters, 2009). They should contain a hook to catch readers' attention. One possibility is to focus on the benefits of community gardens, such as the amount of food produced or money saved. You may want to mention specific benefits if you are targeting certain groups (youth, seniors, food stamp recipients, etc.).

- Flyers and brochures are low cost and easy to create. Partners or community members may also help distribute these flyers door-to-door to improve coverage.

- Putting up a sign at your community garden site is another option if your site is centrally located and in a public space (Hansen et al., 2012).

- Social media can also be used depending on your community. Creating a Facebook page or Twitter account may help spread the word to the community. Keep in mind that many people do not have access to the Internet in their homes.

- Radio or television commercials may also be possible if you have enough funding.

\section{Hold an informational meeting}

Step 15: Hold an initial informational meeting to inform a broad audience and build interest in your project. Invite all members of the community to participate. During this meeting, you can explain the project, get feedback, and create support in the community (Gardening Matters, 2009).

- Hold this meeting at a central location in the community. This can be at a school, church, public building, park, or even at your garden site. Sometimes attendance at initial meetings can be low. Holding the meeting closer to where people live can help. Many apartment complexes have common rooms that are easily obtained for meetings. In some cases, you can knock on doors to increase attendance.

- During the meeting, ask how best to stay in contact with attendees. Some people may provide phone numbers or e-mail addresses. Also be sure that everyone who attends has your contact information.

- Be respectful and accommodating of all community members. Try to understand their concerns, be flexible, and express appreciation for their contributions.

Step 16: Provide information about the benefits of community gardens at this meeting. You are trying to convince people to participate, so focus on the benefits that are most important to your community. The information you learned from your needs assessment can be helpful here. Economic benefits (food savings, sale of produce, etc.) can also be strong motivators. Other motivators can come from partners.

\section{Identify participants}

Step 17: The initial community meeting can also help narrow down the people who might participate in the project. Think about how many people your project needs and try to create a list of possible participants. One strategy is to focus on those individuals who show the strongest interest. During the meeting, these might be the most vocal or positive attendees. However, other people may be interested even if they are less outspoken. Talking with people oneon-one or in small groups are ways to learn if less vocal individuals want to participate (Swisher et al. 2003). It is important to realize that not everyone will be interested or see the value in community gardens. Rather than trying to convince these people, thank them for their contributions and move on.

\section{Follow up after the meeting}

Step 18: Contact members of your community soon after the meeting. Use the sign-up sheets or information from the community meeting to contact the people who attended. This follow up can be very helpful in building trust and encouraging people to participate in the project.

- First, thank everyone who came to the meeting for attending and contributing. This simple act can be very meaningful and prompt people to start/continue with the project. This conversation is also another chance to explain the project one-on-one. Make sure each person understands the details and feels free to ask questions. Inform each community member of the next project meeting and ask them to attend.

- Remind community members that they can contact you with questions or for more information at any time. Make yourself available through several means. Telephone may 
be preferable since people may not have consistent access to e-mail. When you do receive questions or requests for information, respond promptly.

\section{Conduct participatory planning meetings}

Step 19: During the time between the initial meeting and the planting date, interested participants should be invited to a series of planning meetings. These meetings have two goals: (1) to build trust and partnership and (2) to involve participants in the planning process.

- Successful garden projects require communities and project organizers to work together. Partnership and trust are developed over time and through frequent contact. This process takes time, especially when people have diverse backgrounds. These meetings should show that you value community input and appreciate people's participation in project meetings. Giving attendees something garden related (e.g., seeds, potted plants, herbs) to take home when you hold meetings can also reward participation.

Participants in your project should also be involved in project planning. Allowing community members true decision-making power can help them take ownership of garden projects (Swisher et al., 2003).

- The project should be accommodating and inclusive. Ask participants about reasons why people in the community might not participate in the project. These might include education level, language, no gardening experience, or lack of transportation. Any effort to remove these barriers increases participation and shows that participants' needs are important.

- The project overview (steps 11-13) should be flexible to accommodate local input. Suggestions and changes should be sought during meetings or contact with community members.

- Participants should also identify their own goals for the project. Often they have a better idea of how the garden can benefit their community. These can be incorporated into the project's logic model.

- Project names are one opportunity to include local input. Allowing participants to pick a name that best represents their community is an easy way to gain local buy-in.

- Community input also helps create the schedule of activities. Participants know their own training needs and how they can be met by the project.
- Participants can also help with gardening decisions even if they have no previous gardening experience. Creating a list of plants (with pictures) helps people decide what to grow. Plot size could also benefit from community input. If the objective is for the gardening skills learned through the project to be transferred back to small spaces near participants' homes or apartments, they know best what size plots are appropriate. Plot assignment should also be discussed so that participants are satisfied with the plots they receive.

- All community gardens should have a set of rules for participation (Gardening Matters, 2009). Project organizers should work with participants to draft a contract that is fair and transparent. Rules made by participants are more likely to be followed and enforced.

\section{Finalize project plan}

Step 20: After meetings with your advisory committee, project team, and community participants, you should have made decisions about project operations.

- Your logic model should have been changed to include new input from the project team and community. The project's goals should be clear and agreed upon at this point.

- The project schedule should also be ready to implement. Information about local planting and growing times should be used. Training needs should be known and included in the calendar of activities. All activities should be planned backwards from harvest. There should also be flexibility and room for changes during project operations.

- A budget should be prepared for the project based on input from partners and participants (Gardening Matters, 2009). This should include any materials, time, or other costs. Also include partner contributions in your budget.

\section{Early implementation}

Step 21: At this stage, the steps needed before starting gardening activities should be complete (see Checklist).

- You should have created partnerships, developed your project objectives and operating plan, and built up a group of participants. You are ready to start gardening! Begin to implement your project's activities and training as planned. 
- There may still be minor changes needed as the project is conducted. Continue to be flexible as people work in the community garden. Project operations should also be participatory when possible. If your project successfully uses local input and/or participant leaders emerge, be prepared to share management responsibilities with your gardeners.

\section{Checklist}

1. Have you brainstormed some general locations for your garden project? $\quad$ Yes No

2. Have you thought about the needs/opportunities for different areas? $\quad$ Yes No

3. Have you narrowed down the potential areas for your community garden? $\quad$ Yes No

4. Have you selected a garden site for your project? $\quad$ Yes No

5. Have you identified and contacted current garden projects in your city? $\quad$ Yes No

6. Have you included partners whose support is needed for your project? $\quad$ Yes No

7. Have you included partners based on your project's needs? $\quad$ Yes No

8. Have you partnered with community organizations? $\quad$ Yes No

9. Have you identified and included influential community leaders? $\quad$ Yes No

10. Have you created an advisory council for your garden project? $\quad$ Yes No

11. Have you created a logic model for your garden project? $\quad$ Yes No

12. Have you drafted a tentative schedule for your community garden project? $\quad$ Yes No

13. Have you created a plan of activities for the growing period of your project? $\quad$ Yes No

14. Have you used informational materials to introduce the project to your community? Yes No

15. Have you held an initial informational meeting with your community? $\quad$ Yes No

16. Have you explained the benefits of community gardening at your meeting? $\quad$ Yes No

17. Have you identified possible participants for your garden project? $\quad$ Yes No

18. Have you made contact with attendees to follow up after the initial meeting? $\quad$ Yes No

19. Have you conducted participatory planning meetings with community members? Yes No

20. Have you finalized the project's operational plan? $\quad$ Yes No

21. Are you prepared to begin gardening activities? $\quad$ Yes No 


\section{References}

American Community Gardening Association (ACGA). (n.d.). What is a community garden? Retrieved from http:// www.communitygarden.org/learn/

Food and Agriculture Organization (FAO). (n.d.). Reconnaissance visit and transect walk. Retrieved from http:// www.fao.org/fileadmin/templates/nr/kagera/Documents/ LADA_manuals/part2_b.pdf

Gardening Matters. (2009). Twin cities community garden start-up guide. Retrieved from http://www.gardeningmatters.org/sites/default/files/startupguide.pdf

Hansen, G., Sewards, J., Almeida, R., \& Dunn, A. (2012). Design and implementation of edible plant demonstration gardens. ENH1205. Gainesville: University of Florida Institute of Food and Agricultural Sciences. Retrieved from http://edis.ifas.ufl.edu/ep466

Israel, G. (2010). Logic model basics. WC106. Gainesville: University of Florida Institute of Food and Agricultural Sciences. Retrieved from http://edis.ifas.ufl.edu/wc106

McKinney, M. (2007). Empowering and motivating NDSU Extension advisory boards and committees: A hands-on, practical approach. Retrieved from http://www.ag.ndsu. edu/ext-employees/documents/advisory-council-guide
Public Health Law Center (PHLC). (2012). Community garden policy reference guide. Retrieved from http:// publichealthlawcenter.org/sites/default/files/resources/ PHLC\%20Community\%20Garden\%20Policy\%20Guide\%20 2012_0.pdf

Swisher, M., Rezola, S., \& Sterns, J. (2003). Sustainable community development step 3: Create a community vision and develop a roadmap. FCS7216-Eng. Gainesville: University of Florida Institute of Food and Agricultural Sciences. Retrieved from http://edis.ifas.ufl.edu/cd027

University of Wisconsin Extension. (2012). Logic model. Retrieved from http://www.uwex.edu/ces/pdande/evaluation/evallogicmodel.html

Worden, E., Hunsberger, A., \& McLaughlin, J. (2002). Starting a community garden. ENH966. Gainesville: University of Florida Institute of Food and Agricultural Sciences. Retrieved from http://edis.ifas.ufl.edu/ep124 